\title{
Shaking Table Model Test and FE Analysis of a Reinforced Concrete Mega-Frame Structure with Tuned Mass Dampers
}

\author{
Qing Jiang ${ }^{1,2}$, Xinzheng $\mathrm{Lu}^{1 *}$, Hong Guan ${ }^{3}$ and Xianguo $\mathrm{Ye}^{2}$ \\ ${ }^{1}$ Key Laboratory of Civil Engineering Safety and Durability of China Education Ministry, Department of Civil \\ Engineering, Tsinghua University, Beijing, 100084, P.R. China; \\ ${ }^{2}$ School of Civil Engineering, Hefei University of Technology, Hefei 23009, P.R. China; \\ ${ }^{3}$ Griffith School of Engineering, Griffith University Gold Coast Campus, Queensland 4222, Australia
}

\begin{abstract}
SUMMARY
To study the damage characteristics and to evaluate the overall seismic performance of reinforced concrete (RC) mega-frame structures, a shaking table test of a 1/25 scaled model with a rooftop tuned mass damper (TMD) is performed. The maximum deformation and acceleration responses are measured. The dynamic behavior and the damping effect with and without TMD are compared. The results indicate that the mega-frame structure has excellent seismic performance and the TMD device has a significant vibration reduction effect. A finite element (FE) model simulating the scaled model is also developed, and the numerical and experimental results are compared to provide a better understanding of the overall structural behavior in particular those related to the dynamic characteristics and damping effect. Upon verification of the FE model, other important structural behavior can also be predicted by the FE analysis.
\end{abstract}

KEY WORDS: reinforced concrete; mega-frame structures; high-rise buildings; tuned mass damper; shaking table test; vibration reduction effect; finite element analysis; dynamic characteristic; displacement response; damage characteristics

\section{INTRODUCTION}

During the last decade, a large number of super high-rise buildings have been constructed throughout the world; some have become major city landmarks. According to 2012 statistical data from the Council on Tall Buildings and Urban Habitat (CTBUH) (http://buildingdb.ctbuh.org/), approximately 782 super high-rise buildings taller than $200 \mathrm{~m}$ were completed globally at the beginning of 2012. In view of the fact that many different structural systems have been adopted in these super high-rise buildings, evaluating and quantifying the most advantageous structural system are becoming an important and challenging research topic. Khan (1969) studied the most suitable height for different structural systems based on the structural efficiency and proposed the

\footnotetext{
Corresponding author. Tel: +86-10-62795364; fax: +86-10-62795364
}

E-mail address: luxz@tsinghua.edu.cn 
"Heights for Structural Systems" diagrams. These diagrams have been further updated by Khan $(1972,1973)$ who suggested that super high-rise buildings should adopt three-dimensional structural systems, such as shear walls, frame-shear wall structures, belt trusses, and various other tubular systems. Based on the distribution of the primary lateral load-resisting system components within a building, Ali and Moon (2007) classified tall building structural systems into two general categories: interior structures and exterior structures. The interior structures include rigid frame, braced hinged frame, shear-wall/hinged frame, shear wall (or shear truss)-frame interaction systems, and outrigger structures. The exterior structures include tube, diagrid, spatial truss, exoskeleton and mega-frame. Their studies indicate that the mega-frame system has the largest efficient height limitation among all structural systems. The efficient height limitation for RC mega-frame structures can reach 100 stories and for steel mega-frame structures, 160 stories. Therefore with rapid development of construction technologies for super tall buildings, RC mega-frame structures will become one of the most common and effective structural systems in the near future.

The lateral (wind and seismic) loads are the controlling factors in super high-rise building designs. Taranath (1997) indicated that the best structural system for a super high-rise building positions the major lateral load-resisting components as far as possible from the center of the building to efficiently improve the lateral stiffness of the structure. Note that a mega-frame structural system is composed of a mega-frame in resisting both gravity and lateral loads, and a number of substructures which are located between two mega-beams and designed for their own gravity loads only. Such a structural system is considered a perfect fit for the concept of the best structural system (Kim and Jung, 2013). In a mega-frame structure, the corner mega-columns are constructed with shear walls and the mega-beams are constructed with transfer floor trusses. The substructures are generally moment-resisting frames, which are supported by the mega-beams (i.e., transfer floor trusses). Such a system has the following advantages: (1) efficient and economic use of resources by incorporating different materials for the mega-frame and the substructures; (2) flexibility to meet special architectural or functional requirements; (3) better structural performance and integration; and (4) quicker and easier construction. Although very limited theoretical and experimental research has been conducted in this area (Kim and Jung, 2013; Feng and Mita, 1995; Zhang et al., 2005; Shu et al., 2005; and Lan et al., 2004), existing research outcomes indicate that the mega-frame structure has outstanding seismic performance. Nevertheless, limited study has been conducted to investigate how to efficiently control the vibration of mega-frame structures subjected to earthquakes.

The TMD is a passive energy absorbing device used to reduce undesirable vibration under wind and seismic loads. It is well suited for vibration control within tall and super high-rise buildings. In particular, TMDs have been widely installed in super high-rise buildings to control wind-induced vibrations (Kim et al., 2008; Irwin et al., 2009; Lu and Chen, 2011). Although TMDs have been installed in a number of tall and super-tall buildings: the Chiba Port Tower (Ohtake et al., 1992), Milad Tower (Ghorbani-Tanha et al., 2009), John Hancock Tower (Ghosh and Basu, 2007), Sydney Tower (Kwok and 
Macdonald, 1990), Canada's National Tower (Kourakis, 2007), Taipei 101 Tower (Kourakis, 2007) and Shanghai World Financial Center Tower (Lu et al., 2012a), little work is reported on the efficiency of TMD systems to reduce the earthquake-induced vibration of super high-rise buildings.

The shaking table test is one of the most effective methods to study and evaluate the seismic performance of complex buildings. Many researchers, including Li et al. (2006), Lu et al. (2012b), and Ko and Lee (2006), have conducted scaled model tests on shaking tables to study the seismic performance of tall and super high-rise buildings. The scaling ratios of the models ranged from $1 / 12$ to $1 / 50$. These shaking table tests have provided important references for the present work.

To study the damage characteristics and to evaluate the overall seismic performance and vibration reduction of mega-frame structures, a shaking table test of a 1/25 scaled model with a rooftop TMD is performed. The test results indicate that the mega-frame structure has excellent seismic performance and the TMD device has a significant vibration reduction effect. A finite element (FE) model of the same scaled model is also developed and the numerical and experimental results are compared to provide a better understanding of the overall structural behavior in particular those related to the dynamic characteristics and damping effect. Upon verification of the FE model, other important structural behaviors can also be predicted by the FE analysis.

\section{PROTOTYPE BUILDING}

The prototype building considered in this study is an RC mega-frame structure designed following the Chinese design code: the Technical Specifications for Concrete Structures of Tall Building (TSCSTB, JGJ3-2002) and Code for Seismic Design of Buildings (CSDB, GB50011-2010). The prototype building is assumed to be located in a region with a 7-degree seismic design intensity. The corresponding peak ground acceleration (PGA) value of the design earthquake (i.e., probability of exceedance of $10 \%$ in 50 years) is $100 \mathrm{~cm} / \mathrm{s}^{2}$. The site condition is site-class II. The design wind load is $0.35 \mathrm{kN} / \mathrm{m}^{2}$.

As shown in Figures 1-3, the building has a total height of $201 \mathrm{~m}$ and 55 stories. The planar layout of the building is $39 \mathrm{~m} \times 36 \mathrm{~m}$. The mega-columns are constructed with four $7.8 \mathrm{~m} \times 7.2 \mathrm{~m}$ rectangular $\mathrm{RC}$ tubes arranged at the four corners of the building. Each mega-column is constructed with four shear walls. The mega-beam stories located at the 11th, 22nd, 33rd, 44th, and 55th floors are constructed with spatial trusses with a height of $4.2 \mathrm{~m}$ for each (Figure 1 and Figure 2). The floor slab thickness on each mega-beam story is $200 \mathrm{~mm}$. The five identical substructures within the mega-frame are moment-resisting frames. In order to achieve large usable space and prevent axial force transfer from one substructure to the next, the top of each substructure is separated from the mega-beam story above it. Thus, the gravity load of the substructure is completely supported by the corresponding mega-beam story below. The stories immediately above 
and below each mega-beam story (MBS) are referred to hereafter as MBS-U and MBS-D, respectively, as indicated in Figure 1. The thickness and concrete strength of the shear walls are also given in Figure 1. The substructure story height is $3.6 \mathrm{~m}$ and the floor slab thickness on each story is $100 \mathrm{~mm}$. The planar layout of a typical story is presented in Figure 3.

\section{EXPERIMENT}

The 1/25 scaled model test was performed using the shaking table facility in the State Key Laboratory for Disaster Reduction in Civil Engineering of Tongji University, Shanghai, China. The weights of the superstructure, the attached mass and the basement are $4.5 \mathrm{t}, 9.0 \mathrm{t}$ and $3.6 \mathrm{t}$, respectively (see Figure 4). The total weight of the model is $17.1 \mathrm{t}$. The model is fully fixed on the shaking table and the interaction between the foundation and soil is not considered.

\subsection{Materials used for the test model}

According to the work of Sabnis et al. (1983) and Lu (2007), the materials used in the experimental model should maintain similar stress-strain relationship and have lower Young's modulus and higher density than the materials used in the prototype building. For the test model, microconcrete is adopted because its mechanical behavior (cracking or crushing) is similar to normal concrete. Copper which has a smaller stiffness and a larger density is used to represent the fabricated steel, and steel wires are used to represent the reinforcing bars and stirrups as in the prototype building.

\subsection{Similarity ratio}

There are three major controlling scaling factors in the similarity design of the test model: dimension $\left(S_{l}\right)$, elastic modulus $\left(S_{E}\right)$ and acceleration $\left(S_{a}\right)$. Based on the existing experiments for buildings in the similar height range ( $\mathrm{Li}$ et al., 2006; Lu et al., 2012a; Lu et al., 2012b), 1/25 (i.e., $S_{l}=0.04$ ) is considered a suitable scale. The total height of the test model is $8.04 \mathrm{~m}$. Based on the pre-determined material test results of the shaking table test model, $S_{E}$ is determined as 0.35 . Considering the capacity of the shaking table, the scaling factor of acceleration $S_{a}$ is set to 4 . All the other scaling factors are derived from these three factors and are listed in Table 1.

The details of the structural members are designed using the similarity ratios given in Table 1. The longitudinal reinforcement and the stirrups are designed according to the equivalent bending moments and shear forces of the prototype building, respectively. Iron blocks are placed on each floor as additional mass to compensate the difference in the vertical load between the test model and the prototype building, as shown in Table 2. 


\subsection{Design of TMD}

Den Hartong (1956) proposed the optimized frequency and damping ratio for a TMD system as:

$$
f=\frac{1}{1+\mu}, \xi=\sqrt{\frac{3 \mu}{8(1+\mu)}}
$$

where $\mu$ is the mass ratio and is expressed as:

$$
\mu=m / M
$$

and $m$ is the mass of TMD. $M$ is the modal mass of the structure.

Equation (1) is further modified by Sadek et al. (1997) as:

$$
f=\frac{1}{1+\mu \Phi}\left[1-\beta \sqrt{\frac{\mu \Phi}{1+\mu \Phi}}\right], \quad \xi=\Phi\left[\frac{\beta}{1+\mu}+\sqrt{\frac{\mu}{1+\mu}}\right]
$$

where $\Phi$ is the vector of the vibration mode and $\beta$ is the damping ratio. Zhou (1997) and Zuo and Nayfeh (2005) studied the influence of mass ratio $\mu$ on the vibration reduction effect and concluded that a larger $\mu$ yielded a better vibration reduction effect. However, if $\mu>5 \%$, the influence of increased mass on the vibration reduction effect becomes insignificant.

The damper (see Figure 5) is installed on the top of the test model along the $\mathrm{X}$ direction (see Figure 4). The ratio of the damper mass to the first modal mass of the test $\mu$ is approximately $4 \%(214 \mathrm{~kg})$. According to the optimized frequency and damping ratio computed by Equation (3), the damping ratio is set to 5\% and the TMD vibration period is $0.51 \mathrm{~s}$, which is very close to the first vibration period of the test modal $(0.5128 \mathrm{~s})$.

\subsection{Ground motion input}

Four seismic ground motions are input into the shaking table during the test: (1) El-Centro ground motion $\left(\mathrm{PGA}=341.7 \mathrm{~cm} / \mathrm{s}^{2}\right)$, (2) Wenchuan ground motion $(\mathrm{PGA}=$ $\left.824.1 \mathrm{~cm} / \mathrm{s}^{2}\right)$, (3) Chi-Chi ground motion $\left(\mathrm{PGA}=341.5 \mathrm{~cm} / \mathrm{s}^{2}\right)$, and (4) an artificial accelerogram (Wang, 2010). Figures 6 shows the artificial accelerogram time history and the corresponding elastic response spectrums with 5\% damping, in which $S_{T}$ (see Table 1) is not considered. The comparison of the response spectrums to those of the design code (CSDB, GB50011-2010) is also illustrated.

\subsection{Load cases}

The load cases representing the test procedure are listed in Table 3. They are designated according to input excitation, direction and design peak value of the input acceleration. Note that "-D" denotes the test with TMD. The similarity ratios given in Table 1 are used to scale the acceleration and time. A white-noise test is conducted to investigate the change in the vibration period of the test model before and after each load case. Most of the tests are performed in the TMD-controlled direction (i.e., $\mathrm{X}$ direction) which is also 
the weak axis of the test model. To study the differences among one-dimensional, two-dimensional (2D, represented by "Y") and three-dimensional (3D, represented by "Z") seismic responses, 2D and 3D ground motions are also used as input. According to the Code for Seismic Design of Buildings (CSDB, GB50011-2010), the PGAs along the $\mathrm{X}, \mathrm{Y}$ and $\mathrm{Z}$ directions should be 1:0.85:0.65 for a multi-directional input.

Note that following the case CCX5-D, the first period of the test model is found to be $0.833 \mathrm{~s}$ (see Table 4), which is quite different from the period of the TMD, thereby resulting in an insignificant vibration reduction effect by the TMD device. Therefore the TMD are all locked following the case CCX5-D.

\section{TEST RESULTS}

\subsection{Dynamic characteristics}

The natural frequencies and mode shapes of the test model are obtained through white-noise scan tests. Figures 7-8 display the first four vibration mode shapes without TMD (i.e., TMD is locked) and with TMD (i.e., TMD is active). The Fourier spectrums on the top of the structure with and without TMD subjected to white noise input are shown in Figure 9 for WN1 and WN1-D. Table 4 compares the first four vibration periods. The results indicate that the TMD system increases the first vibration period of the model by $14.3 \%$ over the uncontrolled one. Figure 9 demonstrates that the first mode plays an important role in the dynamic response. Therefore, when TMD is installed, the response of the first vibration mode is significantly reduced, which results in a reduced response of the overall structure. As evident in Table 4, under minor (i.e., $\mathrm{PGA}=0.14 \mathrm{~g}$, see Table 3) and moderate earthquakes (i.e., PGA $=0.40 \mathrm{~g}$ ), the period of the model in both the $\mathrm{X}$ and $\mathrm{Y}$ directions increases slightly for WN2 and WN4 as compared to WN1. Thus, the model still behaves elastically during these tests, although some micro-cracks occur. When subjected to severe earthquakes (i.e., PGA $=0.88 \mathrm{~g}$ ) corresponding to a return period of 2500 years, the period in the $\mathrm{X}$ direction increases more than that in the Y direction. The $37.6 \%$ increase from WN1 to WN5 implies that the structure is seriously damaged without a total collapse.

\subsection{Displacement response}

The displacements of the test model are obtained through integration of the acceleration. The acceleration signals are smoothed and filtered prior to their integration. Note that the input PGAs of the load cases with and without TMD are slightly different. For example, Table 3 indicates that the PGA of load case RX2 is $0.376 \mathrm{~g}$ whereas that of load case RX2-D is $0.374 \mathrm{~g}$. To minimize such discrepancy during the displacement comparison, a factor $\alpha$ is defined as:

$$
\alpha=\frac{\mathrm{PGA}}{\mathrm{PGA}_{D}}
$$


where PGA and $\mathrm{PGA}_{D}$ are the PGAs of load cases without and with TMD, respectively. Thus, the displacement of the load cases with TMD is further modified as:

$$
\tilde{D}_{D}=\alpha \cdot D_{D}
$$

where $D_{D}$ and $\tilde{D}_{D}$ are the original and modified displacements, respectively.

Figures 10-12 present the relative displacement envelope of typical load cases for representative PGAs in the $\mathrm{X}$ direction. The deformation modes of the test model are closer to that of a cantilever shear-beam than to that of a conventional high-rise building. The mega-columns and mega-beams limit the deformation mode of the building which can be approximated to a five-story mega-frame structure. It can also be noted in Figures 10 and 11 that the TMD provides a significant vibration reduction effect. Figure 12 further demonstrates that under the same PGA, the displacements of Chi-Chi and Wenchuan ground motions (Figure 12) are obviously larger than that of El-Centro ground motion (Figure 10) and the artificial accelerogram (Figure 11). This confirms the influence of the ground motion characteristics on the dynamic response of the test model. Figure 13 indicates that the relative displacement envelope for load case EY3 (see Table 3) in the X direction is slightly larger than that of EX3.

The displacement time histories when subjected to El-Centro ground motion with $\mathrm{PGA}=0.88 \mathrm{~g}$ and the responses of the model with and without TMD are compared in Figure 14 for EX4 and EX4-D, in which the vibration reduction effect of the TMD can be clearly observed.

\section{COMPARISION OF TEST DATA AND FE ANALYSIS RESULTS}

For better understanding of the overall structural behavior in terms of dynamic characteristics and damping effect, a FE model of the shaking table test is established by using the general-purpose finite-element program MSC.MARC. The material constitutive law and the element model are based on the work of Lu et al. (2013), which are explained in detail as follows. Five element types are used in this FE model (see Table 5).

In this study, the material-based constitutive law is adopted for all components to accurately simulate the nonlinear behavior under the complex stress states (i.e., the coupled axial force, bending moment and shear force). The main construction materials used in the test are microconcrete, copper and steel wires. As such, an elasto-plastic material law and the smeared crack model are adopted for microconcrete in compression and tension, respectively ( $\mathrm{Lu}$ et al., 2013). The von Mises yielding criterion-based plastic constitutive model is adopted for the copper and steel wires. The four-stage (elastic, yield, hardening and post-capping) model proposed by Miao et al. (2011) is adopted as the backbone curve of the stress-strain relationship of steel. The complete FE model of the structure is shown in Figure 15. 


\subsection{Vibration mode of the FE model}

The first four experimental and FE analytical vibration periods along the $\mathrm{X}$ direction are compared in Table 6 which confirms that the results are in good agreement.

\subsection{Time history analysis of the model}

The following results are presented under El-Centro ground motion with a PGA of $0.88 \mathrm{~g}$. Figure 16 compares the experimental and numerical displacement envelopes. The FE results are in excellent agreement with the experimental data.

This comparison confirms that the FE model is accurate. The inter-story drift which cannot be measured in the test can then be predicted by the FE model. Figure 17 illustrates the simulated inter-story drift. The inter-story drifts at the mega-beam stories are much smaller than those of the adjacent regular stories, which significantly reduce the cumulative inter-story drift of the structure. However, such a sudden stiffness change induces stress concentrations on the stories adjacent to each mega-beam story (i.e., MBS-U and MBS-D stories). Consequently, the inter-story drifts of MBS-U and MBS-D are significantly larger than those of the other stories. When designing such structural systems, a special strengthening scheme should be adopted for the MBS-U and MBS-D stories to avoid damage in these regions.

\section{CONCLUSIONS}

From the experimental and numerical results presented in this paper, the following three conclusions can be drawn:

(1) The shaking table test results indicate that the test model suffers little damage under the design level earthquake load (ground motion of PGA $=0.4 \mathrm{~g}$ ). It can also meet the collapse prevention requirements for severe earthquakes (ground motion of PGA = $0.88 \mathrm{~g}$ ). Therefore, the prototype structure is able to satisfy the seismic performance demand of 7- degree seismic design intensity.

(2) The displacement envelope of the mega-frame structure exhibits a shear dominated mode, and the first vibration mode plays an important role in its dynamic response. After the installation of TMD, the first vibration period is increased and the time-history displacement is reduced, suggesting that the TMD can be used for effective vibration control for super tall mega-frame buildings.

(3) The FE results agree well with test data which confirms the accuracy of the FE analysis. The FE results demonstrate that the inter-story drifts at the mega-beam stories are much smaller than those at the adjacent stories (i.e., MBS-D and MBS-U), which significantly reduce the cumulative inter-story drift of the structure. However, the inter-storey drifts of MBS-U and MBS-D stories are obviously larger than those of the other stories, which should be designed with special strengthening scheme.

Upon verification of the FE model, the damage mechanism, collapse resistance and 
parameter optimization of TMD, which cannot be readily identified in the laboratory test, will be further studied in the future. The outcomes can be directly used to guide the design of mega-frame structures alike.

\section{ACKNOWLEDGEMENT}

The authors are grateful for the financial support received from the National Nature Science Foundation of China (No. 51222804, 91315301, 51261120377), the Fok Ying Dong Education Foundation (No. 131071) and the State Key Laboratory for Disaster Reduction in Civil Engineering Foundation (SLDRCE08-HZ-01).

\section{REFERENCES}

Ali MM, Moon KS. 2007. Structural developments in tall buildings: current trends and future prospects. Architectural Science Review. 50(3): 205-223.

China Ministry of Construction. 2010. Code for Seismic Design of Buildings (GB50011-2010). China Architecture and Building Press: Beijing, China (English edn).

China Ministry of Construction. 2002. Technical Specification for Concrete Structures of Tall Building (JGJ3-2002). China Architecture and Building Press: Beijing, China (in Chinese).

Den Hartog JP. 1956. Mechanical Vibration, 4th edn. McGraw-Hill: New York, USA.

Feng MQ, Mita A. 1995. Vibration control of tall buildings using mega subconfiguration. Journal of Engineering Mechanics. 121 (10): 1082-1088.

Ghorbani-Tanha AK, Noorzad A, Rahimian M. 2009. Mitigation of wind-induced motion of Milad Tower by tuned mass damper. The Structural Design of Tall and Special Buildings. 18(4): 371-385.

Ghosh A, Basu B. 2007. A closed-form optimal tuning criterion for TMD in damped structures. Structural Control and Health Monitoring. 14(4): 681-692.

Irwin P, Kilpatrick J, Robinson J, et al. 2008. Wind and tall buildings: negatives and positives. The Structural Design of Tall and Special Buildings. 17(5): 915-928.

Khan FR. 1969. Recent structural systems in steel for high-rise buildings. In Proceedings of the British Constructional Steelwork Association Conference on Steel in Architecture. London: British Constructional Steelwork Association.

Khan FR. 1972. Influence of design criteria on selection of structural systems for tall buildings, In Proceedings of the Canadian Structural Engineering Conference. Toronto: Canadian Steel Industries Construction Council,1-15.

Khan FR. 1973. Evolution of structural systems for high-rise buildings in steel and concrete. In J. Kozak (Ed.), Tall Buildings in the Middle and East Europe: Proceedings of the $10^{\text {th }}$ Regional Conference on Tall Buildings-Planning. Design and Construction. Bratislava: Czechoslovak Scientific and Technical Association.

Kim J, Jung M. 2013. Progressive collapse-resisting capacity of modular mega-frame buildings. The Structural Design of Tall and Special Buildings. 22(6): 471-484.

Kim YM, You KP, Kim HY. 2008. Wind-induced excitation control of a tall building with tuned mass 
dampers. The Structural Design of Tall and Special Buildings. 17(3): 669-682.

Ko DW, Lee HS. 2006, Shaking table tests on a high-rise RC building model having torsional eccentricity in soft lower storeys. Earthquake Engineering \& Structural Dynamics. 35(11):1425-1451.

Kourakis I. 2007. Structural systems and tuned mass dampers of super-tall buildings: case study of Taipei 101. Doctoral dissertation, Massachusetts Institute of Technology, Cambridge, USA

Kwok KCS, Macdonald PA. 1990. Full-scale measurement of wind-include acceleration response of Sydney Tower. Engineering Structures. 12(3): 153-162.

Lan ZJ, Tian YJ, Fang L, Liang ST, Wang X.D. 2004. An experimental study on seismic responses of multifunctional vibration-absorption reinforced concrete megaframe structures. Earthquake Engineering \& Structural Dynamics. 33(1): 11-14.

Li CS, Lam SS, Zhang MZ, Wong YL. 2006, Shaking table test of a 1:20 scale high-rise building with a transfer plate system. Journal of Structural Engineering. 132(11): 1732-1744.

Lu X, Lu XZ, Guan H, Ye LP. 2013. Collapse simulation of reinforced concrete high-rise building induced by extreme earthquakes, Earthquake Engineering \& Structural Dynamics. 42(5): 705-723.

Lu X, Chen J. 2011. Mitigation of wind - induced response of Shanghai Center Tower by tuned mass damper. The Structural Design of Tall and Special Buildings. 20(4): 435-452.

Lu XL, Chen Y, Mao YJ. 2012b. Shaking table model test and numerical analysis of a supertall building with high-level transfer storey. The Structural Design of Tall and Special Buildings. 21(10): 699-723.

Lu XL, Li P, Guo X, Shi W, Liu J. 2012a. Vibration control using ATMD and site measurements on the Shanghai World Financial Center Tower. The Structural Design of Tall and Special Buildings. Doi: $10.1002 /$ tal.1027

Lu XL. 2007, Seismic Theory and Application of Complex High-Rise Building Structure. Science Press: Beijing, China (in Chinese).

Miao ZW, Ye LP, Guan H, Lu XZ. 2011. Evaluation of modal and traditional pushover analyses in frame-shear-wall structures, Advances in Structural Engineering. 14(5): 815-836.

Ohtake K, Mataki Y, Ohkuma T, Kanda J, Kitamura H. 1992. Full-scale measurements of wind actions on Chiba Port Tower. Journal of Wind Engineering and Industrial Aerodynamics. 43(1): 2225-2236.

Sabnis GM, Harris HG, White RN, Mirza MS. 1983. Structural Modeling and Experimental Techniques. Prentice-Hall: Engle-wood Cliffs, NJ USA.

Sadek F, Mohraz B, Taylor AW, Chung RM. 1997. A method of estimating the parameters of tuned mass dampers for seismic applications. Earthquake Engineering and Structural Dynamics. 26(6): 617-635.

Shu GP, Zhang YF, Lu ZT, Zuo J, Xia CC, Jiang H. 2005. The aseismic capability and shaking table experiment of mega-frame structures. SISS 2005: Innovation \& Sustainability of Structures. 1-3: $398-414$

Taranath BS. 1997. Steel, Concrete, and Composite Design of Tall Buildings, McGraw Hill: New York, NY.

Wang DC. 2010. Research on energy spectrum and the selection of earthquake accelerograms for dynamic analysis based on energy. Doctoral dissertation, Hefei University of Technology, Hefei, China (in Chinese).

Zhang XA, Zhang JL, Wang D, Jiang JS. 2005. Controlling characteristic of passive mega-subcontrolled frame subjected to random wind loads. Journal of Engineering Mechanics 131(10): 1046-1055. 
Zhou FL. 1997. Engineering structural vibration control. Seismological Press: Beijing, China (in Chinese).

Zuo L, Nayfeh SA. 2005. Optimization of the individual stiffness and damping parameters in multiple-tuned-mass-damper systems. Transactions of the ASME-L-Journal of Vibration and Acoustics. 127(1): 77-83. 


\section{List of Tables}

Table 1 Scaling factors

Table 2 Weights of iron blocks on different floors

Table 3 Test procedure

Table 4 The first four vibration periods of the test model

Table 5. Elements used to model the structural components

Table 6 Experimental and FE analytical vibration periods

\section{List of Figures}

Figure 1 Structural layout of the mega-frame

Figure 2 Three-dimensional view of a typical mega-beam story

Figure 3 Plan layout of a typical substructure story (units: $\mathrm{mm}$ )

Figure 4 Photo of the shaking table model

Figure 5. The installation of TMD

Figure 6. Artificial accelerogram

Figure 7 Elastic modal shapes in $\mathrm{X}$ direction without TMD

Figure 8 Elastic modal shapes in $\mathrm{X}$ direction with TMD

Figure 9 Fourier spectrums at the top of the model with and without TMD subjected to white noise

Figure 10 Displacement envelope in X direction under El-Centro ground motion

Figure 11 Displacement envelope in $\mathrm{X}$ direction under artificial accelerogram

Figure 12 Displacement envelope in $\mathrm{X}$ direction under other ground motions

Figure 13 Displacement envelope in X direction of load case EX3 and EY3

Figure 14 Lateral displacement responses under El-Centro ground motion of $0.88 \mathrm{~g}$

Figure 15 The FE model

Figure 16 Displacement envelope under El Centro ground motion of $0.88 \mathrm{~g}$

Figure 17 Inter-story drifts under El Centro ground motion of $0.88 \mathrm{~g}$ 
Table 1 Scaling factors

\begin{tabular}{|c|c|c|c|}
\hline & Design parameter & Expression & Scaling factor \\
\hline \multirow{5}{*}{ Material } & Strain, $\varepsilon$ & $S_{\varepsilon}$ & 1 \\
\hline & Stress, $\sigma$ & $S_{\sigma}$ & 0.35 \\
\hline & Elastic modulus, $E$ & $S_{E}$ & 0.35 \\
\hline & Density, $\rho$ & $S_{\rho}=S_{d} S_{a} \cdot S_{l}$ & 2.118 \\
\hline & Mass, $m$ & $S_{m}=S_{\sigma} S_{l}^{2} / S_{a}$ & 0.00014 \\
\hline \multirow{4}{*}{ Geometrical } & Length, $l$ & $S_{l}$ & 0.04 \\
\hline & Area, $A$ & $S_{A}=S_{l}^{2}$ & 0.0016 \\
\hline & Translational displacement $X$ & $S_{X}=S_{l}$ & 0.04 \\
\hline & Angular displacement $\beta$ & $S_{\beta}$ & 1 \\
\hline \multirow{3}{*}{ Load } & Concentrated load, $F$ & $S_{F}=S_{\sigma} S_{l}^{2}$ & 0.00032 \\
\hline & & & \\
\hline & Area load $p$ & $S_{p}=S_{\sigma}$ & 0.20 \\
\hline \multirow{7}{*}{ Dynamic } & Stiffness, $k$ & $S_{k}=S_{E} S_{l}$ & 0.014 \\
\hline & Period, $T$ & $S_{T}=S_{l}^{0.5} \cdot S_{a}^{-0.5}$ & 0.1 \\
\hline & Frequency, $f$ & $S_{f}=S_{l}^{-0.5} \cdot S_{a}^{0.5}$ & 10 \\
\hline & Damping, $c$ & $S_{c}=S_{\sigma} \cdot S_{l}^{1.5} \cdot S_{a}^{-0.5}$ & 0.0014 \\
\hline & Velocity, $v$ & $S_{v}=\left(S_{l}^{-} \cdot S_{a}\right)^{0.5}$ & 0.118 \\
\hline & Acceleration, $a$ & $S_{a}$ & 4 \\
\hline & Acceleration of gravity, $g$ & $S_{g}$ & 1 \\
\hline
\end{tabular}


Table 2 Weights of iron blocks on different floors

\begin{tabular}{cccccc}
\hline \multicolumn{2}{c}{ Substructure } & \multicolumn{2}{c}{ MBS-D } & \multicolumn{2}{c}{ MBS } \\
\hline Floor & Weight $(\mathrm{kg})$ & Floor & Weight $(\mathrm{kg})$ & Floor & Weight $(\mathrm{kg})$ \\
\hline $1-9,12-13$ & 172 & 10 & 205 & 11 & 253 \\
$14-20,23-24$ & 161 & 21 & 194 & 22 & 240 \\
$25-31,34-35$ & 151 & 32 & 184 & 33 & 228 \\
$36-42$ & 140 & 43 & 173 & 44 & 215 \\
$45-53$ & 140 & 54 & 173 & 55 & 234 \\
\hline
\end{tabular}


Table 3 Test procedure

\begin{tabular}{|c|c|c|c|c|c|c|c|c|c|}
\hline \multirow{2}{*}{$\begin{array}{c}\text { Case } \\
\text { designation }\end{array}$} & \multirow{2}{*}{$\begin{array}{c}\text { Input } \\
\text { excitation }\end{array}$} & \multirow{2}{*}{$\begin{array}{c}\text { With/without } \\
\text { TMD }\end{array}$} & \multirow[t]{2}{*}{ Directions } & \multicolumn{3}{|c|}{$\begin{array}{l}\text { Design peak value of } \\
\text { input acceleration }(\mathrm{g})\end{array}$} & \multicolumn{3}{|c|}{$\begin{array}{l}\text { Actual peak value of } \\
\text { input acceleration }(\mathrm{g})\end{array}$} \\
\hline & & & & $X$ & $\mathrm{Y}$ & $\mathrm{Z}$ & $X$ & $\mathrm{Y}$ & $\mathrm{Z}$ \\
\hline WN1 & White noise & Locked & $X+Y+Z$ & 0.07 & 0.07 & 0.07 & - & - & - \\
\hline EX1 & El-Centro & Locked & X & 0.14 & - & - & 0.136 & - & - \\
\hline RX1 & Artificial & Locked & $\mathrm{X}$ & 0.14 & - & - & 0.181 & - & - \\
\hline EZ1 & El-Centro & Locked & $\mathrm{X}+\mathrm{Y}+\mathrm{Z}$ & 0.14 & 0.119 & 0.119 & 0.13 & 0.23 & 0.04 \\
\hline WN1-D & White noise & Active & $\mathrm{X}+\mathrm{Y}+\mathrm{Z}$ & 0.07 & 0.07 & 0.07 & - & - & - \\
\hline EX1-D & El-Centro & Active & $X$ & 0.14 & - & - & 0.143 & - & - \\
\hline RX1-D & Artificial & Active & $\mathrm{X}$ & 0.14 & - & - & 0.165 & - & - \\
\hline WN2 & White noise & Locked & $X+Y+Z$ & 0.07 & 0.07 & 0.07 & - & - & - \\
\hline EX2 & El-Centro & Locked & X & 0.28 & - & - & 0.321 & - & - \\
\hline $\mathrm{RX} 2$ & Artificial & Locked & $\mathrm{X}$ & 0.28 & - & - & 0.376 & - & - \\
\hline EY2 & El-Centro & Locked & $X+Y$ & 0.28 & 0.238 & - & 0.31 & 0.31 & - \\
\hline EX2-D & El-Centro & Active & $\mathrm{X}$ & 0.28 & - & - & 0.332 & - & - \\
\hline RX2-D & Artificial & Active & X & 0.28 & - & - & 0.374 & - & - \\
\hline WN3 & White noise & Locked & $\mathrm{X}+\mathrm{Y}+\mathrm{Z}$ & 0.07 & 0.07 & 0.07 & - & - & - \\
\hline EX3 & El-Centro & Locked & X & 0.4 & - & - & 0.426 & - & - \\
\hline RX3 & Artificial & Locked & $X$ & 0.4 & - & - & 0.409 & - & - \\
\hline EY3 & El-Centro & Locked & $\mathrm{X}+\mathrm{Y}$ & 0.4 & 0.34 & - & 0.42 & 0.41 & - \\
\hline EX3-D & El-Centro & Active & $\mathrm{X}$ & 0.4 & - & - & 0.426 & - & - \\
\hline RX3-D & Artificial & Active & $\mathrm{X}$ & 0.4 & - & - & 0.408 & - & - \\
\hline WN4 & White noise & Locked & $\mathrm{X}+\mathrm{Y}+\mathrm{Z}$ & 0.07 & 0.07 & 0.07 & - & - & - \\
\hline EX4-D & El-Centro & Active & X & 0.88 & - & - & 1.093 & - & - \\
\hline RX4-D & Artificial & Active & $\mathrm{X}$ & 0.88 & - & - & 0.828 & - & - \\
\hline EX4 & El-Centro & Locked & X & 0.88 & - & - & 0.932 & - & - \\
\hline WN5 & White noise & Locked & $\mathrm{X}+\mathrm{Y}+\mathrm{Z}$ & 0.07 & 0.07 & 0.07 & - & - & - \\
\hline CCX5-D & Chi-Chi & Active & X & 0.88 & - & - & 1.014 & - & - \\
\hline WN6 & White noise & Locked & $X+Y+Z$ & 0.07 & 0.07 & 0.07 & - & - & - \\
\hline EX6 & El-Centro & Locked & X & 1.2 & - & - & 1.222 & - & - \\
\hline CCX6 & Chi-Chi & Locked & $\mathrm{X}$ & 1.2 & - & - & 0.832 & - & - \\
\hline WX6-1 & Wenchuan & Locked & $\mathrm{X}$ & 0.4 & - & - & 0.473 & - & - \\
\hline WX6-2 & Wenchuan & Locked & $\mathrm{X}$ & 0.88 & - & - & 0.875 & - & - \\
\hline WX6-3 & Wenchuan & Locked & $\mathrm{X}$ & 1.2 & - & - & 1.147 & - & - \\
\hline WN7 & White noise & Locked & $X+Y+Z$ & 0.07 & 0.07 & 0.07 & - & - & - \\
\hline
\end{tabular}


Table 4 The first four vibration periods of the test model

\begin{tabular}{ccccccccc}
\hline \multirow{2}{*}{ Case } & \multicolumn{3}{c}{ Vibration periods in X direction $(\mathrm{s})$} & \multicolumn{3}{c}{ Vibration periods in Y direction (s) } \\
\cline { 2 - 8 } designation & $\begin{array}{c}\text { First } \\
\text { mode }\end{array}$ & $\begin{array}{c}\text { Second } \\
\text { mode }\end{array}$ & $\begin{array}{c}\text { Third } \\
\text { mode }\end{array}$ & $\begin{array}{c}\text { Fourth } \\
\text { mode }\end{array}$ & $\begin{array}{c}\text { First } \\
\text { mode }\end{array}$ & $\begin{array}{c}\text { Second } \\
\text { mode }\end{array}$ & $\begin{array}{c}\text { Third } \\
\text { mode }\end{array}$ & $\begin{array}{c}\text { Fourth } \\
\text { mode }\end{array}$ \\
\hline 1WN & 0.510 & 0.158 & 0.074 & 0.045 & 0.513 & 0.147 & 0.070 & 0.043 \\
$1 \mathrm{WN}-\mathrm{D}$ & 0.583 & 0.146 & 0.074 & 0.046 & 0.525 & 0.160 & 0.070 & 0.043 \\
$2 \mathrm{WN}$ & 0.544 & 0.155 & 0.076 & 0.046 & 0.528 & 0.160 & 0.071 & 0.043 \\
$3 \mathrm{WN}$ & 0.583 & 0.158 & 0.079 & 0.048 & 0.562 & 0.160 & 0.071 & 0.044 \\
$4 \mathrm{WN}$ & 0.583 & 0.169 & 0.082 & 0.049 & 0.575 & 0.160 & 0.073 & 0.043 \\
$5 \mathrm{WN}$ & 0.702 & 0.186 & 0.089 & 0.055 & 0.581 & 0.159 & 0.076 & 0.046 \\
$6 \mathrm{WN}$ & 0.833 & 0.243 & 0.110 & 0.064 & 0.595 & 0.190 & 0.082 & 0.051 \\
$7 \mathrm{WN}$ & 0.963 & 0.243 & 0.108 & 0.067 & 0.620 & 0.192 & 0.085 & 0.054 \\
\hline
\end{tabular}


Table 5. Elements used to model the structural components

\begin{tabular}{ll}
\hline \multicolumn{1}{c}{ Element type } & \multicolumn{1}{c}{ Structural components } \\
\hline Spatial beam elements & Beam and columns in the substructure and mega-beams \\
Truss elements & Rebar embedded in shear walls \\
Thin-walled section beam elements & Shaped steel embedded at the boundary of the shear walls \\
Multi-layer shell elements & Shear walls, coupling beams and floor slabs \\
Springs elements & Springs and dampers of TMD \\
\hline
\end{tabular}


Table 6 Experimental and FE analytical vibration periods

\begin{tabular}{ccc}
\hline Period (s) & Test model & FE model \\
\hline First mode & 0.510 & 0.509 \\
Second mode & 0.158 & 0.152 \\
Third mode & 0.074 & 0.075 \\
Fourth mode & 0.045 & 0.046 \\
\hline
\end{tabular}




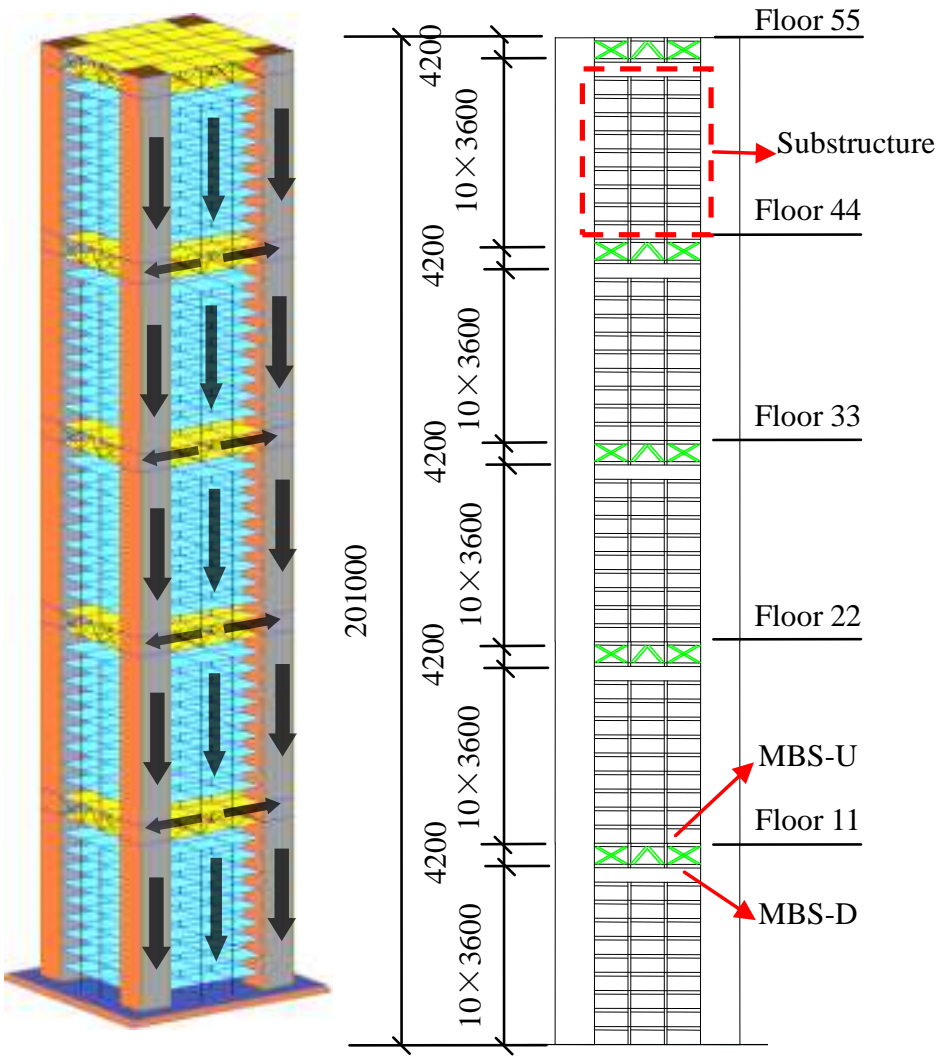

(a) Three-dimensional view

(b) Elevation (units: mm)
Floor Thickness Strength

47 55:400mm C40

39 46: $400 \mathrm{~mm} \mathrm{C40}$

36 38:400 mm C40

28 35: $500 \mathrm{~mm} \mathrm{C40}$

25 27: $500 \mathrm{~mm} \mathrm{C50}$

17 24: 600 mm C50

14 16: 600 mm C60

4 13: 700 mm C60

1 3: 700 mm C60

(c) Shear wall

(Arrows represent gravity load

transfer)

Figure 1 Structural layout of the mega-frame 


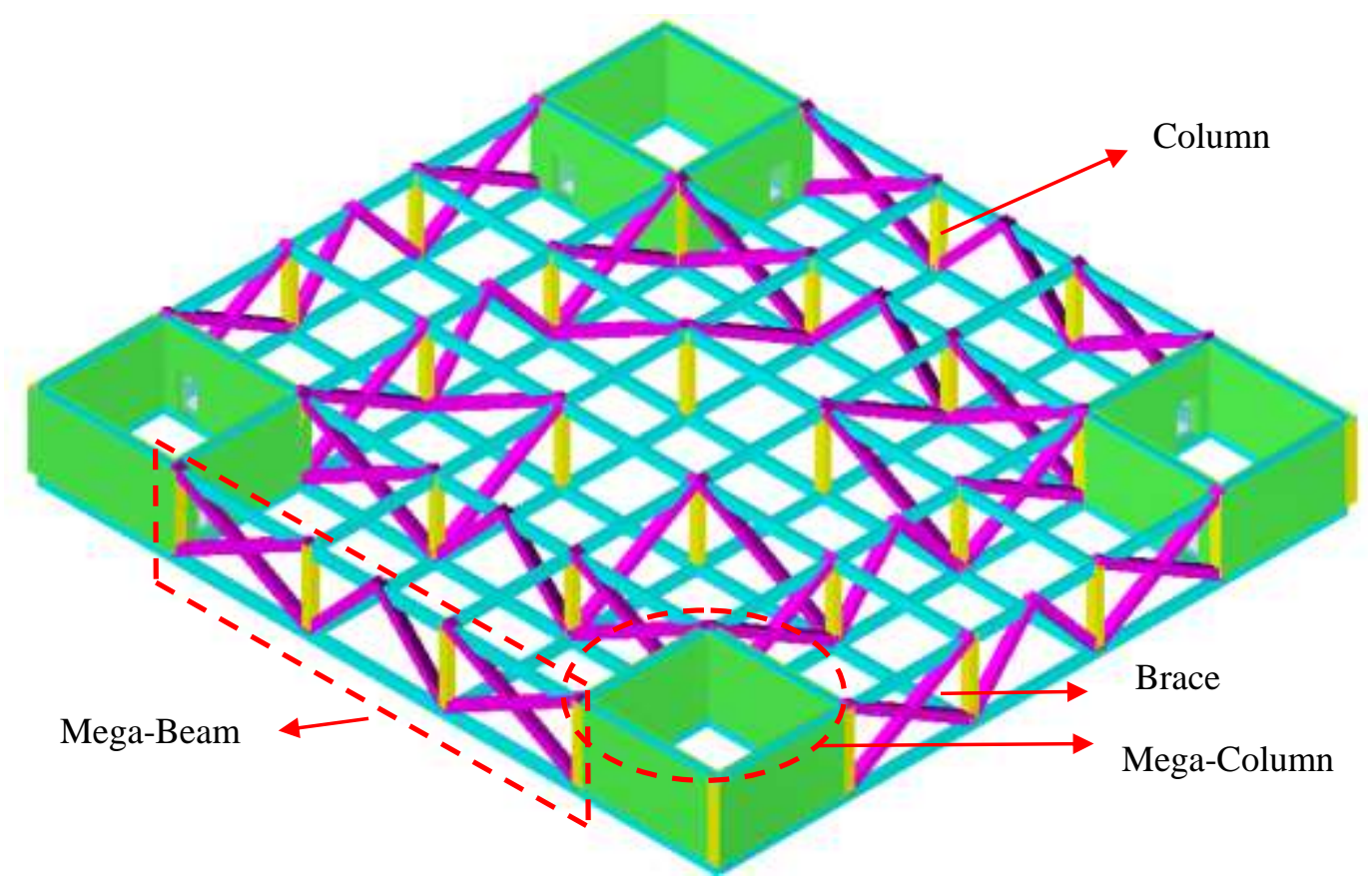

Figure 2 Three-dimensional view of a typical mega-beam story

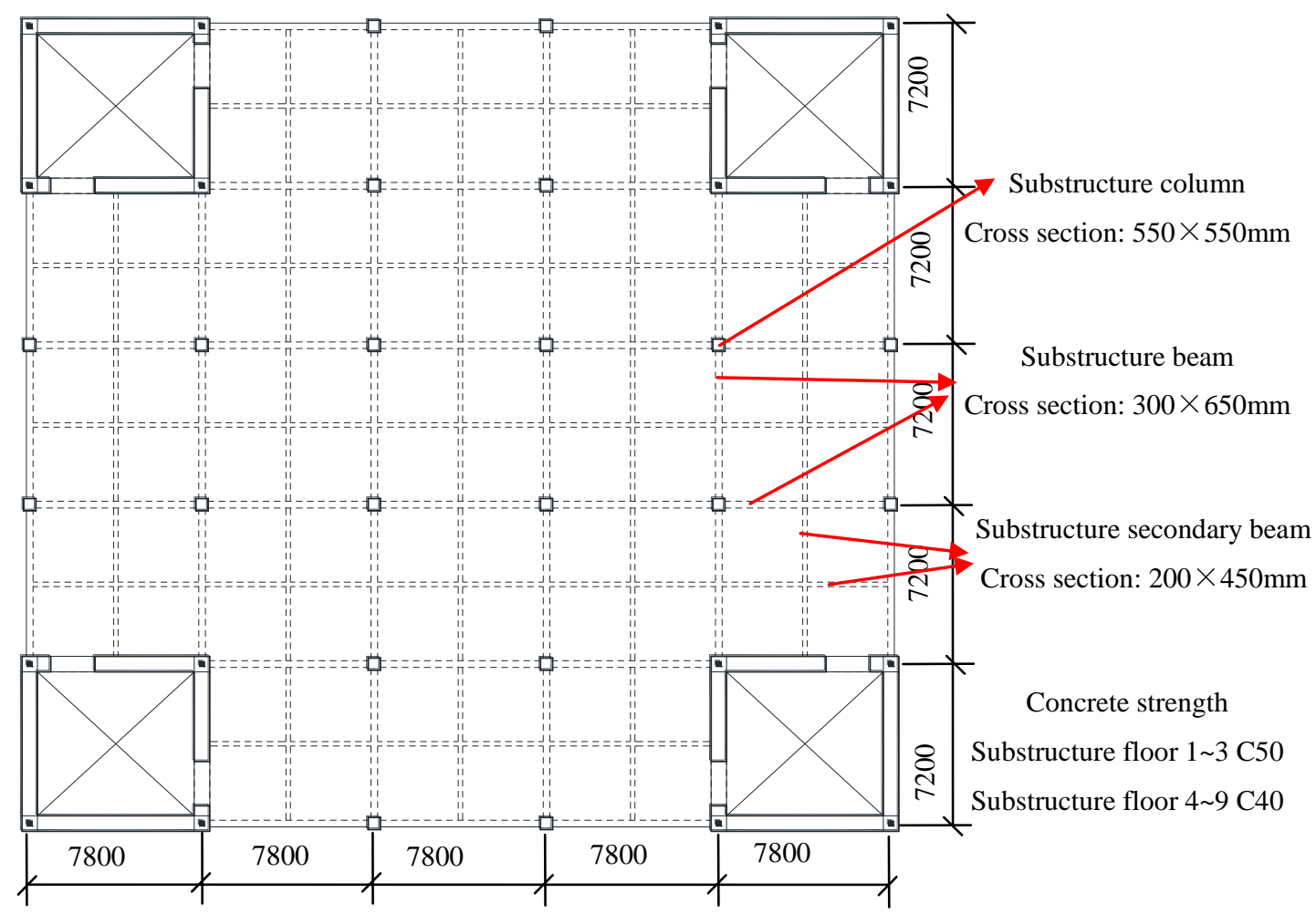

Figure 3 Plan layout of a typical substructure story (units: $\mathrm{mm}$ ) 


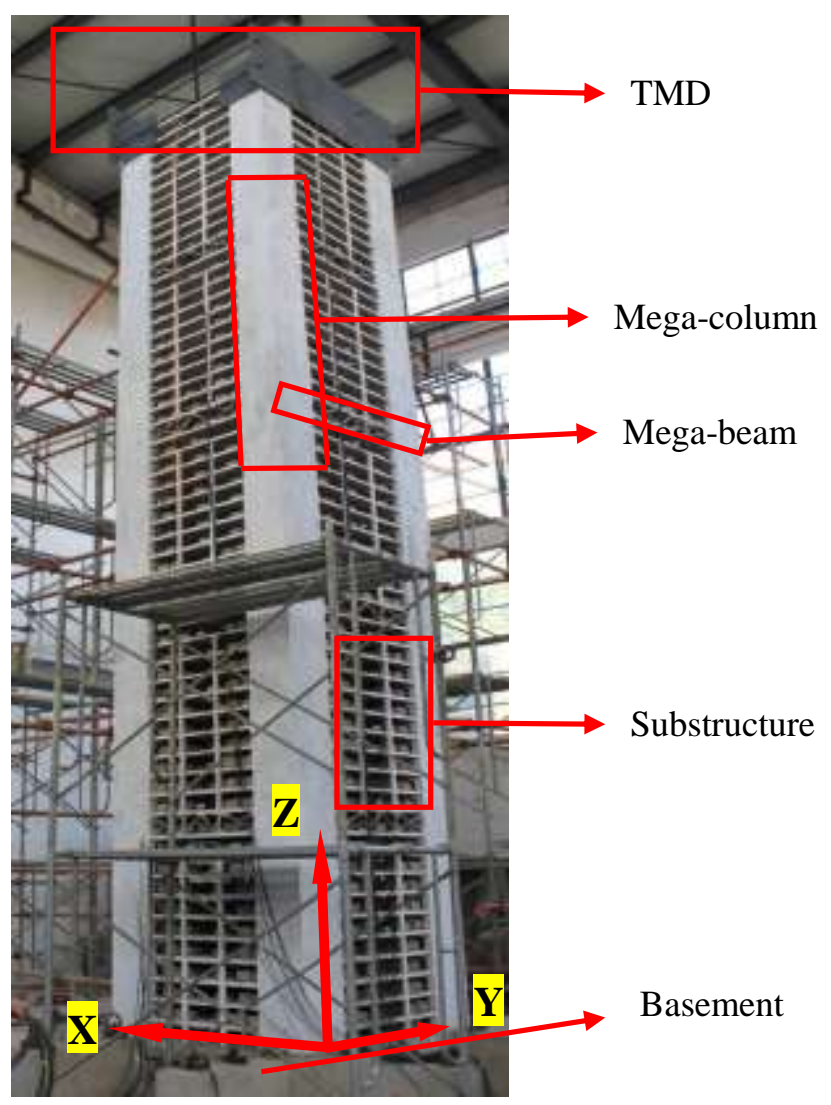

Figure 4 Photo of the shaking table model
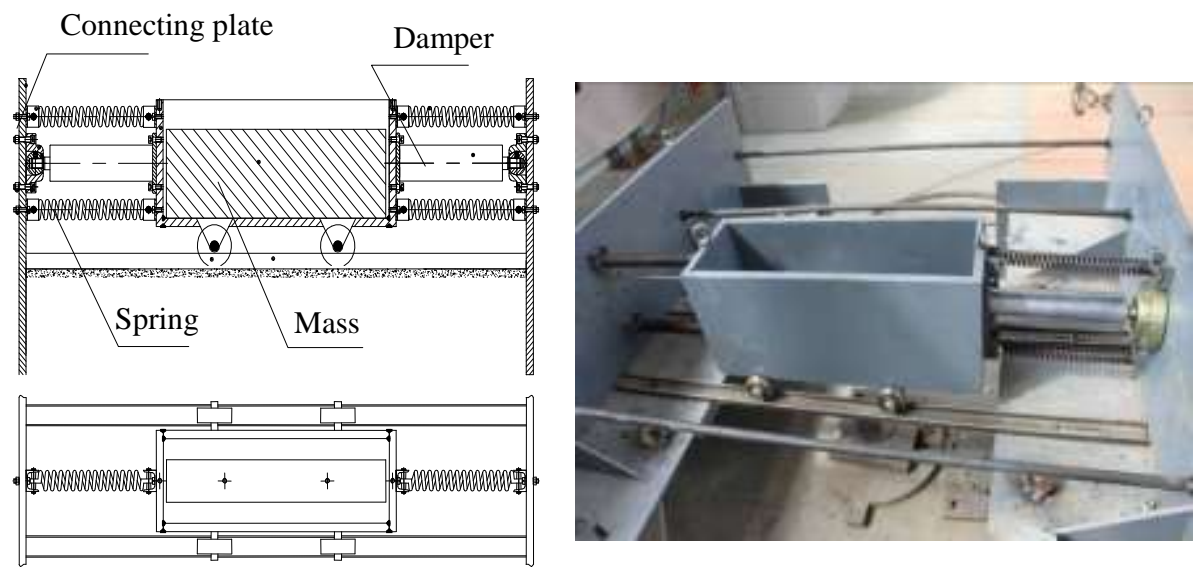

Figure 5 The installation of TMD 


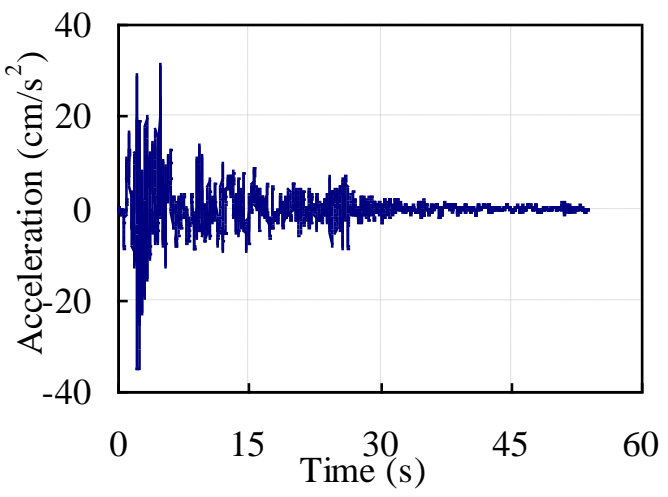

(a) Time history

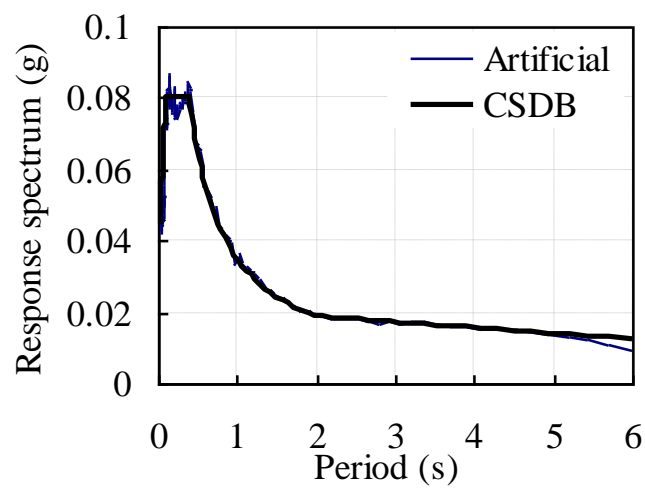

(b) Response spectrum $\left(\mathrm{PGA}=35 \mathrm{~cm} / \mathrm{s}^{2}\right)$

Figure 6. Artificial accelerogram

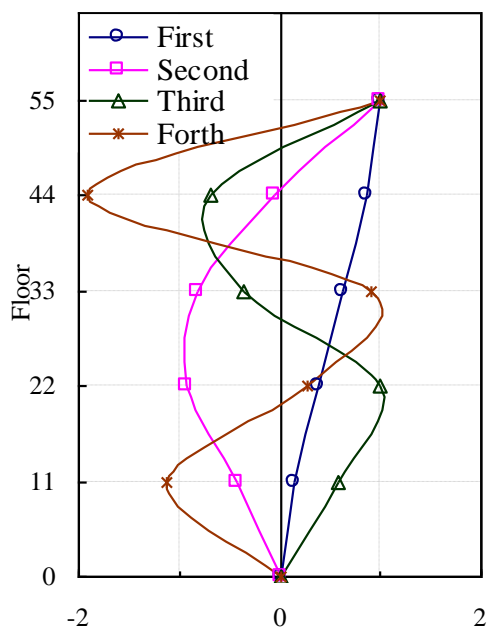

Figure 7 Elastic modal shapes in $\mathrm{X}$ direction without TMD 


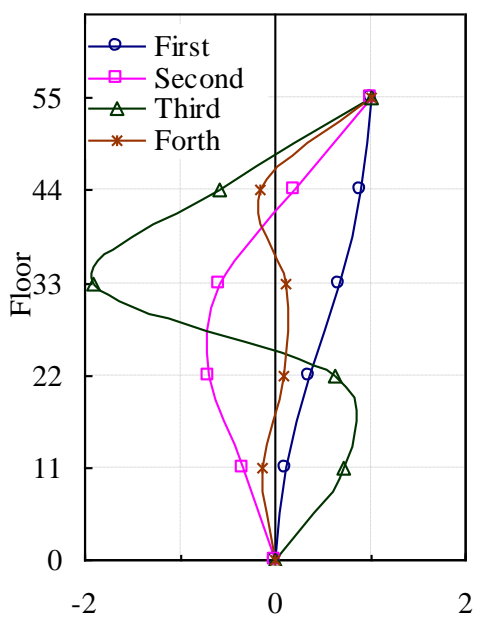

Figure 8 Elastic modal shapes in $\mathrm{X}$ direction with TMD

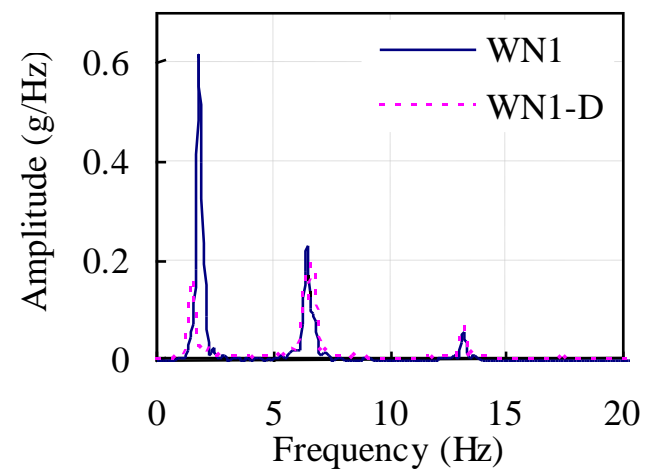

Figure 9 Fourier spectrums at the top of the model with and without TMD subjected to white noise 


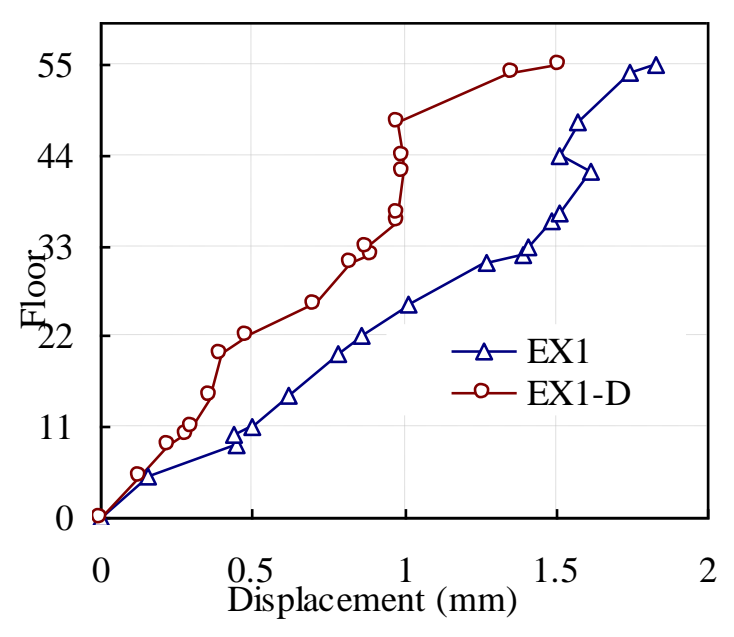

(a) $\mathrm{PGA}=0.14 \mathrm{~g}$

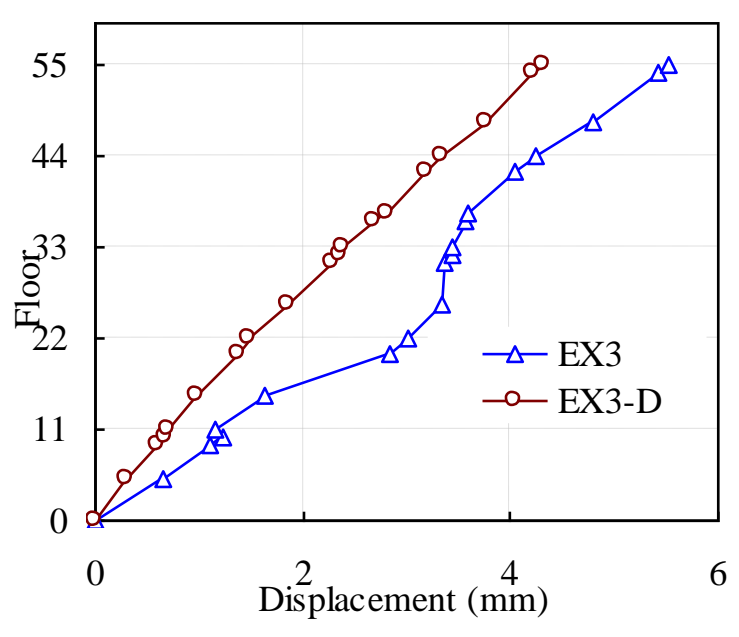

(b) $\mathrm{PGA}=0.4 \mathrm{~g}$

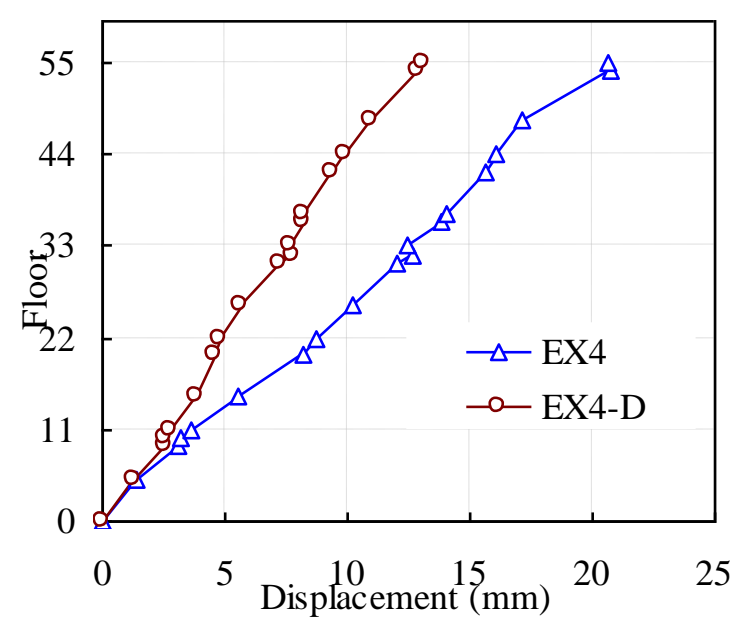

(c) $\mathrm{PGA}=0.88 \mathrm{~g}$

Figure 10 Displacement envelope in $\mathrm{X}$ direction under El-Centro ground motion 


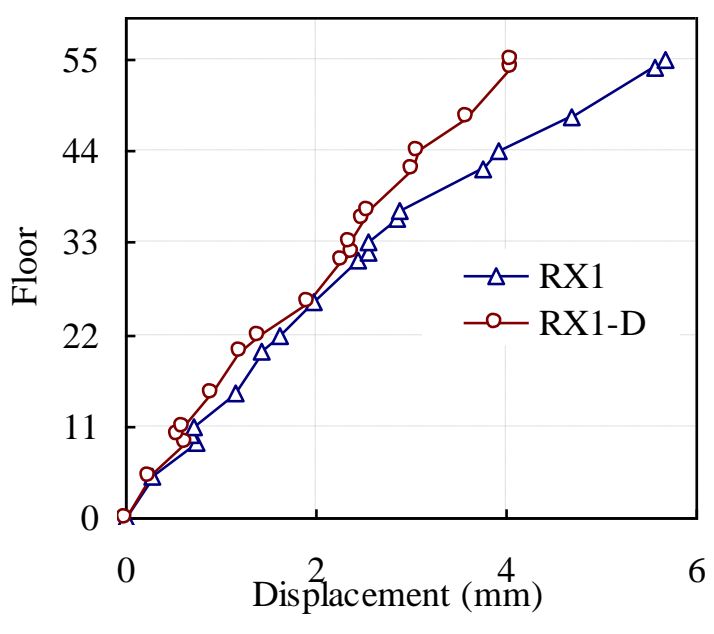

(a) $\mathrm{PGA}=0.14 \mathrm{~g}$

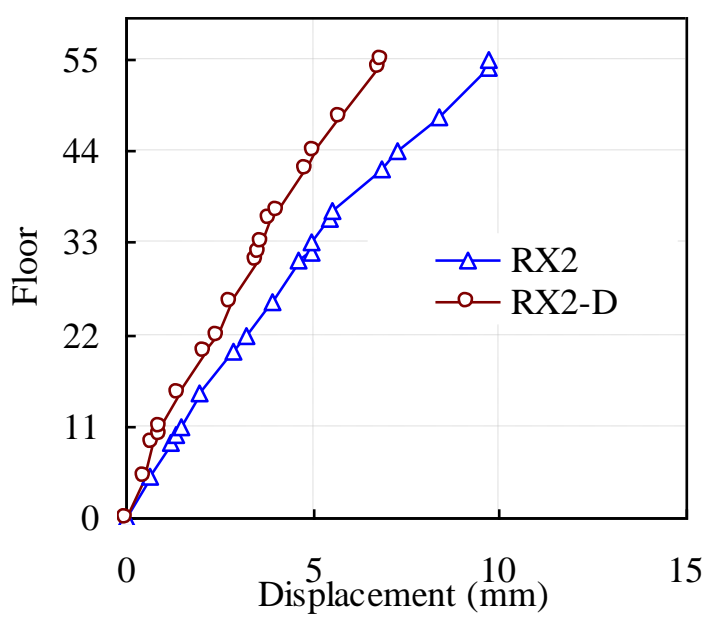

(b) $\mathrm{PGA}=0.28 \mathrm{~g}$

Figure 11 Displacement envelope in $\mathrm{X}$ direction under artificial accelerogram

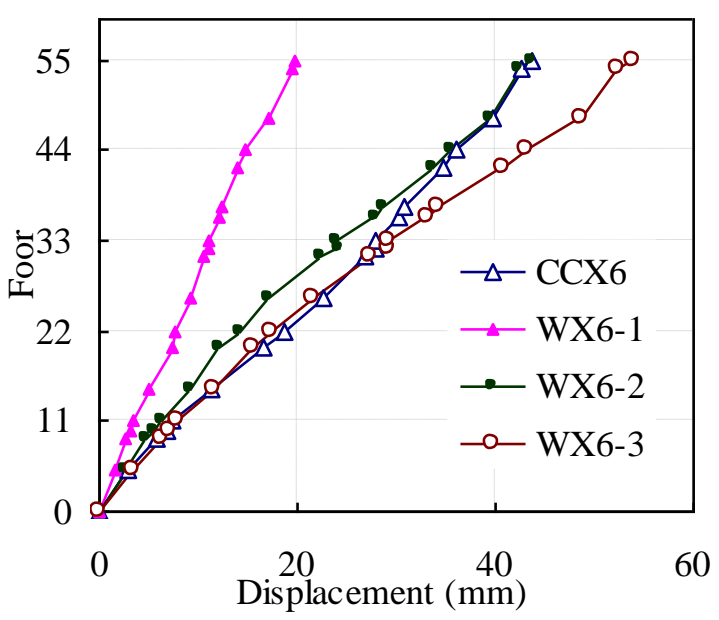

Figure 12 Displacement envelope in $\mathrm{X}$ direction under other ground motions 


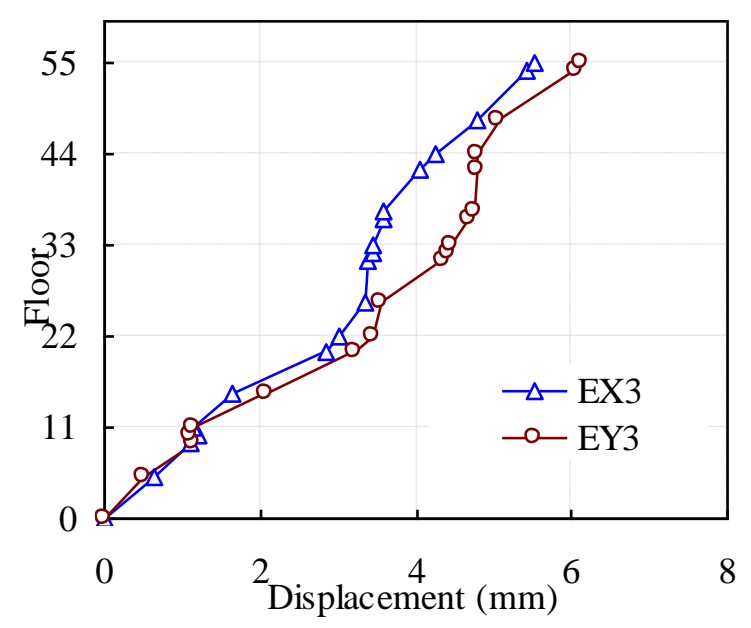

Figure 13 Displacement envelope in X direction of load case EX3 and EY3

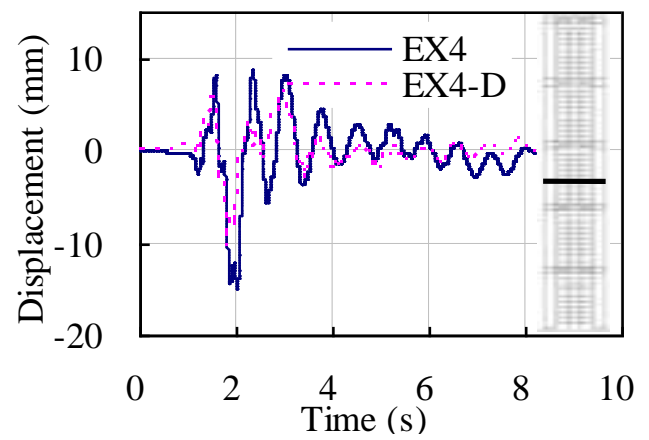

(a) Floor 26 (substructure)

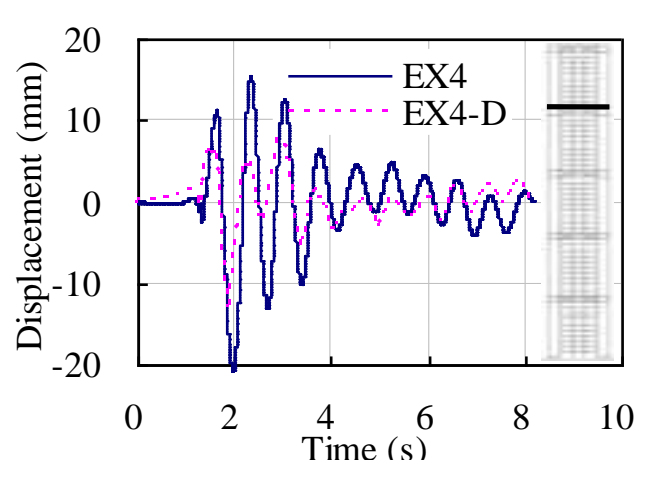

(c) Floor 44 (mega-frame)

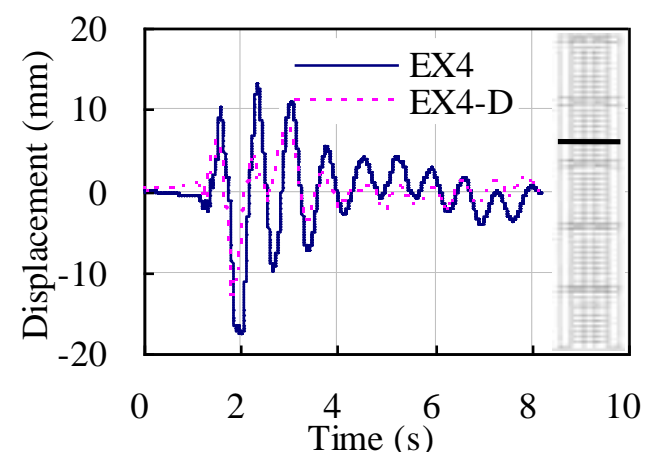

(b) Floor 36 (substructure)

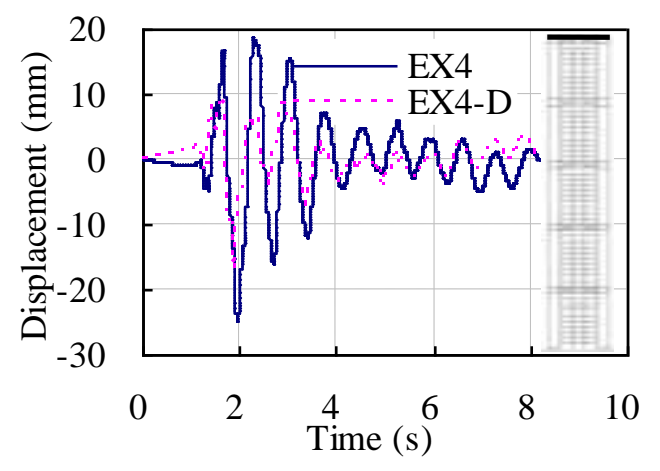

(d) Top floor (mega-frame)

Figure 14 Lateral displacement responses under El-Centro ground motion of $0.88 \mathrm{~g}$ 

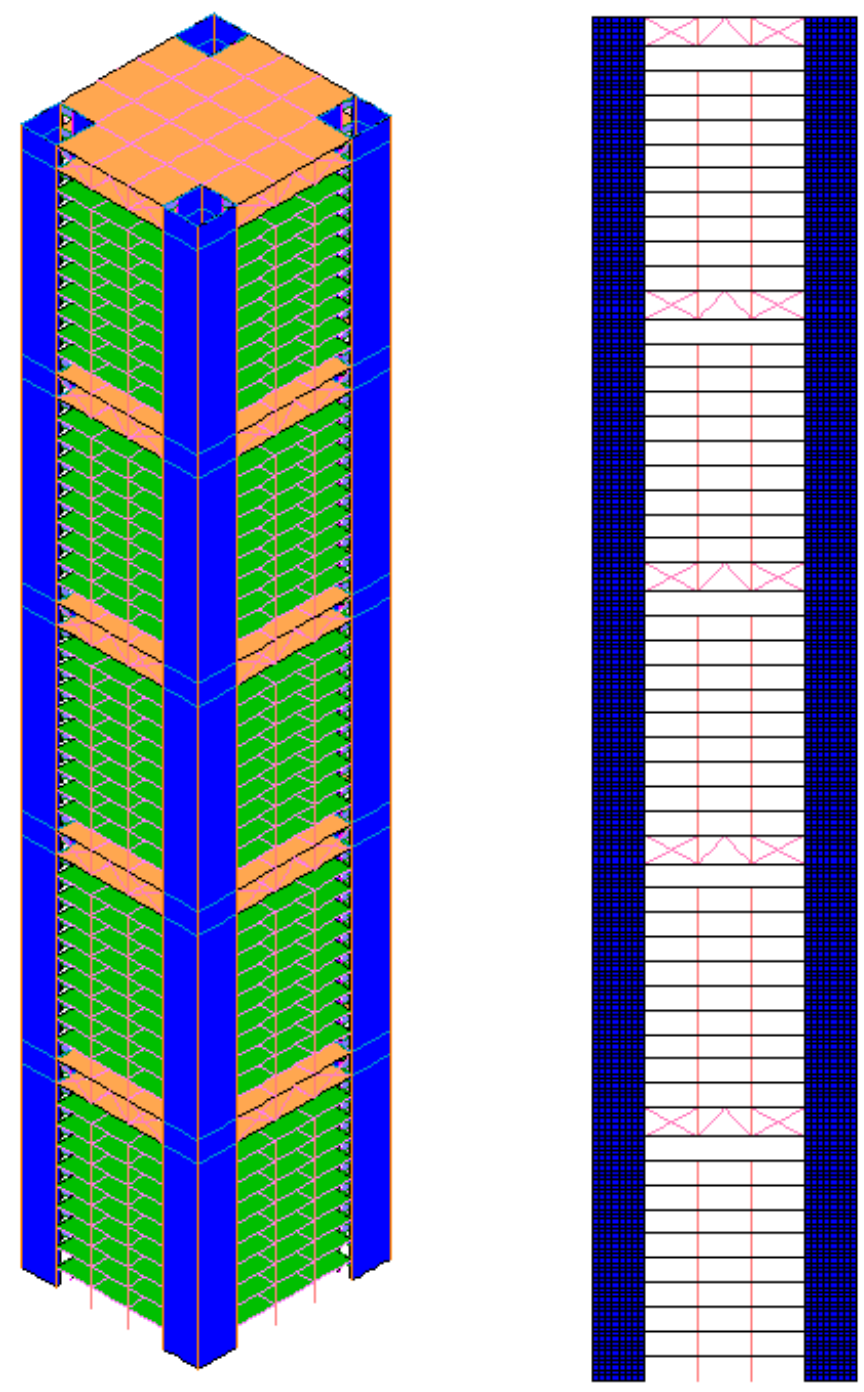

Figure 15 The FE model 


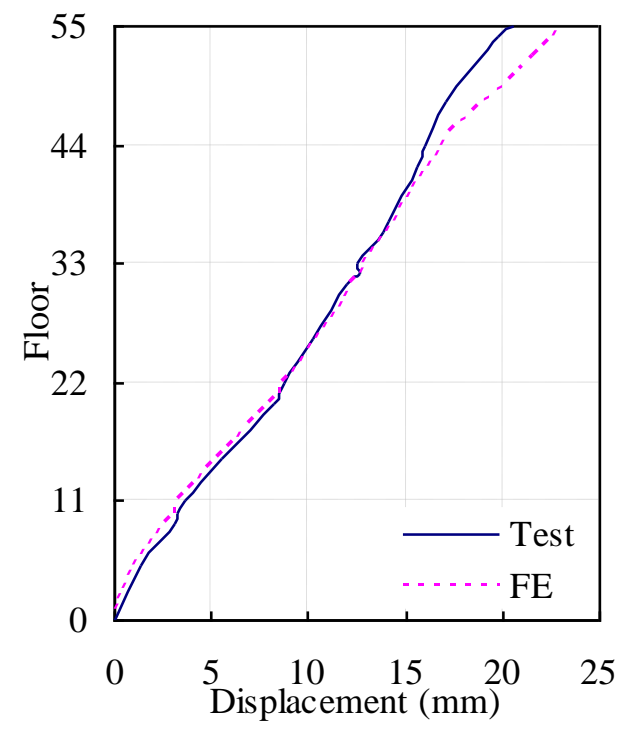

(a) Without TMD

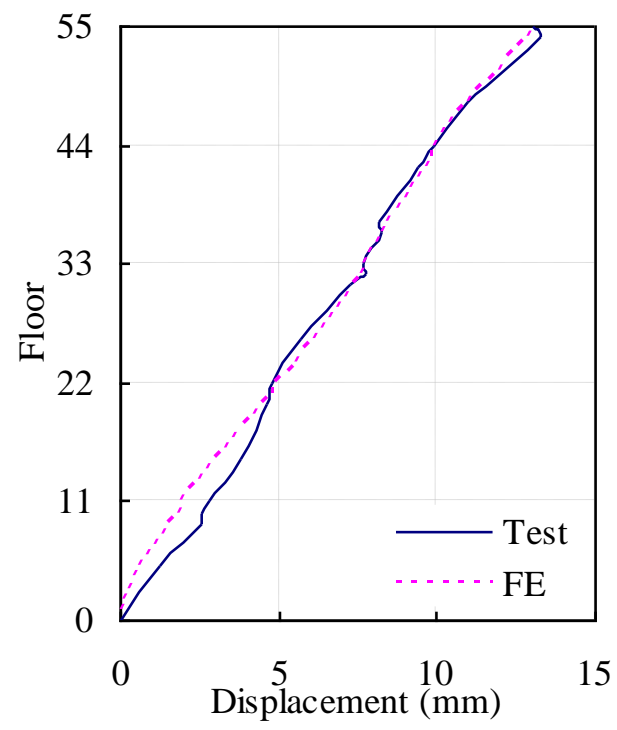

(b) With TMD

Figure 16 Displacement envelope under El Centro ground motion of $0.88 \mathrm{~g}$

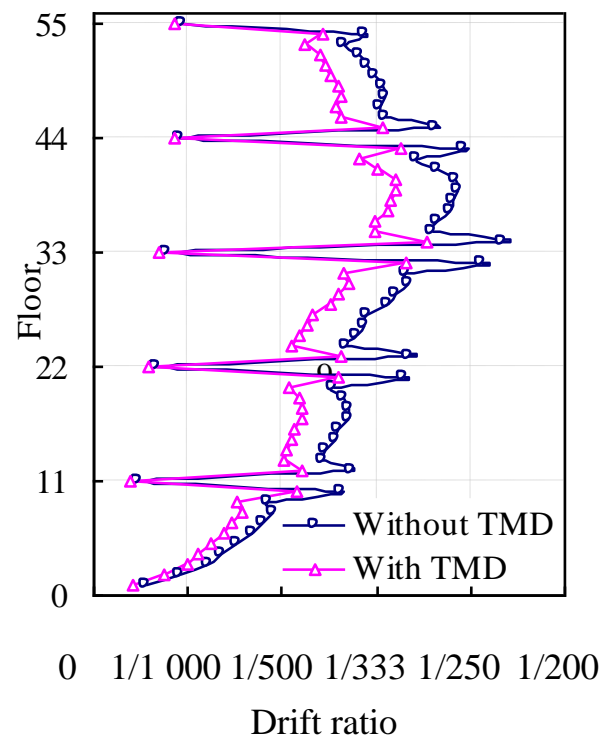

Figure 17 Inter-story drifts under El Centro ground motion of $0.88 \mathrm{~g}$ 